\title{
Pengaruh Model Problem Based Learning (PBL) dan Project Based Learning (PjBL) Terhadap Hasil Belajar Biologi Pada Materi Pencemaran Lingkungan Siswa Sekolah Menengah Atas
}

\author{
Eka Prihatini \\ SMA Negeri 2 Kota Tebingtinggi, Sumatera Utara, 20614 \\ E-mail: echapinky21@yahoo.co.id
}

\begin{abstract}
This research was aimed to determine: the effect of model problem based learning (PBL), project based learning $(\mathrm{PjBL})$ and conventional learning to: biology learning outcomes of students in the matter of environmental pollution in SMA Negeri 2 Kota Tebingtinggi. A quasi-experiment research used pretest-posttest control group design. Samples were selected using random cluster sampling technique and divided into experiment and control classes. The tenth class of sains- 2 was applied with conventional learning (control), the tenth class of sains-3 was applied with problem based learning (PBL), and the tenth class of sains-4 was applied with project based learning (PjBL). Data were analyzed using Analysis Covarian (anacova) at the level of significance $\alpha=0.05$ and followed by Tukey's test with SPSS ver 21.0. The results showed that: There was an effect of learning model to biology learning outcomes $(\mathrm{P}=0,025)$. Biology learning outcomes that learned with problem based learning $(81,46 \pm 6,59)$ was higher than the project based learning $(81,43 \pm 10,14)$ and conventional learning $(65,43 \pm 7,10)$. Based on the results showed that problem based learning (PBL) is better than project based learning $(\mathrm{PjBL})$ and conventional learning.
\end{abstract}

Keywords: Problem Based Learning (PBL), Project Based Learning (PjBL), Conventional Learning, Biology Learning Outcomes.

\section{PENDAHULUAN}

Pendidikan berperan penting dalam membentuk karakter, mental serta potensi yang dimiliki oleh siswa. Melalui pendidikan diharapkan bangsa ini dapat mengikuti perkembangan ilmu pengetahuan dan teknologi yang semakin berkembang. Untuk menciptakan sumber daya manusia yang unggul dan mampu bersaing dalam menghadapi era globalisasi maka diperlukan pendidikan yang berkualitas yang dapat diciptakan melalui pembelajaran bermutu yang mampu mengembangkan potensi yang dimiliki siswa.

Pembelajaran biologi merupakan salah satu sektor penting dalam menghasilkan sumber daya manusia yang kompetitif dan memiliki daya saing. Dalam pembelajaran sains dalam hal ini biologi di sekolah hendaknya tidak berorientasi semata-mata untuk mempersiapkan siswa untuk melanjutkan ke jenjang pendidikan yang lebih tinggi, melainkan menyiapkan siswa untuk (1) mampu memecahkan masalah yang dihadapi dalam kehidupan sehari-hari dengan menggunakan konsep-konsep sains yang telah mereka pelajari; (2) mampu mengambil keputusan yang tepat dengan menggunakan konsep-konsep ilmiah; dan (3) mempunyai sikap ilmiah dalam memecahkan masalah yang dihadapi sehingga memungkinkan mereka untuk berpikir dan bertindak secara ilmiah (Wahyudi, 2002).

Salah satu materi pelajaran biologi yang berkaitan dengan dunia nyata dan dekat dengan kehidupan sehari-hari adalah pencemaran lingkungan. Pembelajaran biologi dapat dilakukan dengan pendekatan teori konstruktivisme. Siswa dapat membangun dan mengembangkan pengetahuannya sendiri melalui pengalaman belajar yang dilakukannya. Para siswa membutuhkan cara belajar aktif yang memungkinkan mereka mendapatkan pengetahuan berdasarkan kegiatan yang mereka lakukan sendiri (Suryosubroto, 2002).

Dari hasil wawancara beberapa guru biologi di Kota Tebingtinggi, mengatakan bahwa dalam proses pembelajaran guru lebih sering menggunakan model pembelajaran konvensional sehingga proses belajar mengajar didominasi oleh guru dan siswanya kurang aktif dan cenderung mendengarkan semua informasi dari guru sebagai satu-satunya sumber belajar, hal ini mengakibatkan minimnya umpan balik dari siswa terhadap materi pelajaran yang dijelaskan oleh guru.

Berdasarkan hasil wawancara beberapa guru biologi di Kota Tebingtinggi, maka peneliti juga mengobservasi dan menemukan hal yang sama terjadi di SMA Negeri 2 Kota Tebingtinggi. Proses pembelajaran biologi masih menghadapi beberapa permasalahan, 
khususnya pada materi pencemaran lingkungan. Siswa tidak aktif dalam pembelajaran, siswa hanya mendengarkan penjelasan dan mencatat materi pelajaran yang disampaikan guru. Hasil observasi di atas dikuatkan dengan rata-rata nilai ujian nasional (UN) biologi siswa SMA Negeri 2 Kota Tebingtinggi dua tahun terakhir sebagai berikut: tahun pelajaran 2012/2013 menunjukkan bahwa rata-rata nilai UN biologi sebesar 8,65 \pm 0,56 dan pada tahun pelajaran 2013/2014 menunjukkan bahwa rata-rata nilai UN biologi sebesar 7,91 $\pm 1,08$.

Dari hasil ini dapat dilihat bahwa hasil belajar biologi siswa SMA Negeri 2 Kota Tebingtinggi kecenderungan mengalami penurunan. Hasil belajar yang dimaksud merupakan hasil belajar pada ranah kognitif. Kecenderungan penurunan nilai hasil belajar siswa SMA Negeri 2 Kota Tebingtinggi sesuai dengan hasil observasi yang peneliti lakukan yaitu penggunaan model pembelajaran yang kurang bervariasi dan lebih dominan menggunakan model pembelajaran konvensional. Berdasarkan hal tersebut maka penting dilakukan penelitian yang mengimplementasikan model pembelajaran yang sesuai dengan pembelajaran biologi yang dekat dengan kehidupan sehari-hari sebagai solusi untuk mengatasi masalah pembelajaran. Salah satu alternatif solusi adalah dengan menggunakan model pembelajaran problem based learning (PBL) dan project based learning $(\mathrm{PjBL})$.

Pembelajaran dengan model problem based learning (PBL) adalah suatu pendekatan pembelajaran dengan model yang menerapkan proses belajar mengajar berorientasi pada masalah yang berkaitan dengan kehidupan nyata. Sejalan dengan ungkapan Cinar (dalam Sembiring: 2014), pembelajaran yang berpusat pada siswa mampu membangkitkan diskusi, dapat meningkatkan kemampuan berpikir kritis dan hasil belajar dengan menerapkan pembelajaran berbasis masalah. Bangun (2012), mengungkapkan bahwa penggunaan problem based learning dapat meningkatkan hasil belajar biologi dibandingkan dengan pembelajaran tradisional.

Seperti halnya dengan model problem based learning (PBL), pembelajaran dengan model project based learning (PjBL) berorientasi pada suatu proyek untuk menghasilkan sebuah produk. Mahanal dkk (2009), menyatakan bahwa ada pengaruh pembelajaran PjBL terhadap peningkatan sikap dan hasil belajar pada materi ekosistem siswa SMA Negeri 2 Malang. Rahmawati (2014), menunjukkan bahwa terjadi peningkatan pengetahuan siswa artinya perilaku siswa mengalami peningkatan yang cukup dengan menerapkan strategi project based learning (PjBL) berbantuan modul pengelolaan sampah berbasis $6 \mathrm{M}$.

Bertolak dari latar belakang di atas, maka perlu diteliti penggunaan kedua model pembelajaran tersebut pada materi pencemaran lingkungan dengan menggunakan permasalahan-permasalahan kontekstual dalam kehidupan sehari-hari siswa agar siswa lebih aktif dan mampu meningkatkan hasilbelajar siswa.

\section{METODE PENELITIAN}

Penelitian ini dilaksanakan di SMA Negeri 2 Kota Tebingtinggi yang berlokasi di jalan K.L. Yos Sudarso km. 5 Kota Tebingtinggi, pada kelas $\mathrm{X}$ semester genap Tahun Pelajaran 2014/2015. Penelitian ini dilakukan mulai bulan Pebruari sampai bulan Mei 2015. Populasi dalam penelitian ini adalah seluruh siswa kelas $X$ IPA SMA Negeri 2 Kota Tebingtinggi semester genap Tahun Pelajaran 2014/2015, yang berjumlah 253 orang yang tersebar dalam 6 kelas yaitu kelas X IPA-1 berjumlah 44 siswa, $X$ IPA-2 berjumlah 44 siswa, $X$ IPA-3 berjumlah 41 siswa, X IPA-4 berjumlah 40 siswa, X IPA-5 berjumlah 42 siswa dan X IPA6 berjumlah 42 siswa. Teknik pengambilan sampel dilakukan dengan cara cluster random sampling (sampel acak berkelompok). Hasil pemilihan sampel menetapkan tiga kelas yaitu kelas X IPA-2, kelas X IPA-3 dan kelas X IPA4. Selanjutnya ditentukan kelas X IPA-2 dengan siswa sebanyak 44 orang sebagai kelompok kontrol yang menerapkan model pembelajaran konvensional, kelas X IPA-3 dengan siswa sebanyak 41 orang sebagai kelompok eksperimen yang menerapkan model problem based learning (PBL) dan kelas X IPA-4 dengan siswa sebanyak 40 orang sebagai kelompok eksperimen yang menerapkan model project based learning (PjBL).

Jenis penelitian yang digunakan adalah eksperimen semu (quasi experiment). Desain penelitian menggunakan Pretest-Posttest Control Group Design. Teknik pengumpulan data yang gunakan adalah teknik tes yang mengukur hasil belajar biologi. Tes ini dilakukan dua kali yaitu sebelum pemberian perlakuan yang bertujuan untuk mengetahui kemampuan awal siswa (pretest) dan sesudah pemberian perlakuan untuk mengetahui kemampuan siswa setelah adannya perlakuan 
(posttest). Instrumen yang digunakan untuk mengukur hasil belajar biologi adalah tes uraian (essay test) yang digunakan meliputi tes awal (pretest) dan tes akhir (posttest) yang terdiri dari 6 soal uraian.

Data hasil penelitian diolah dan dianalisis secara bertahap hipotesis diuji dengan menggunakan rumus analisis covarian (anacova) pada taraf signifikansi $\alpha=0.05$. Ha (terdapat pengaruh) diterima apabila nilai signifikansi $<0.05$ dan sebaliknya. Apabila hasil uji statistik menunjukkan adanya pengaruh, maka analisis dilanjutkan dengan uji Tukey. Pengolahan data dilakukan dengan menggunakan program SPSS ver 21.0.

\section{HASIL DAN PEMBAHASAN}

\section{Hasil}

Hasil uji hipotesis dengan menggunakan analisis covarian (anacova) memperlihatkan bahwa model pembelajaran berpengaruh secara signifikan terhadap hasil belajar siswa dengan nilai $(\mathrm{F}=5,137 ; \mathrm{P}=0,025)$. Berdasarkan pengujian hipotesis, maka $\mathrm{H}_{\mathrm{a}}$ yang menyatakan terdapat pengaruh model problem based learning (PBL), model project based learning (PjBL) dan model pembelajaran konvensional terhadap hasil belajar biologi pada materi pencemaran lingkungan siswa kelas X SMA Negeri 2 kota Tebingtinggi diterima dan $\mathrm{H}_{0}$ ditolak. Hasil uji Tukey's menunjukkan bahwa hasil belajar siswa yang dibelajarkan dengan model problem based learning (PBL) $\overline{\boldsymbol{x}}_{ \pm} \mathrm{SD}$ $81,46 \pm 6.59$ lebih tinggi dibandingkan dengan hasil belajar siswa yang dibelajarkan dengan model project based learning $(\mathrm{PjBL}) \overline{\boldsymbol{X}}_{ \pm} \mathrm{SD}$ $81,43 \pm 10,14$. Hasil belajar siswa yang dibelajarkan dengan model problem based learning (PBL) dan model project based learning $(\mathrm{PjBL})$ lebih tinggi secara signifikan dibandingkan dengan kelas yang dibelajarkan dengan model pembelajaran konvensional $\overline{\boldsymbol{X}}_{ \pm}$ SD 65,43 $\pm 7,10$ (Gambar 1).

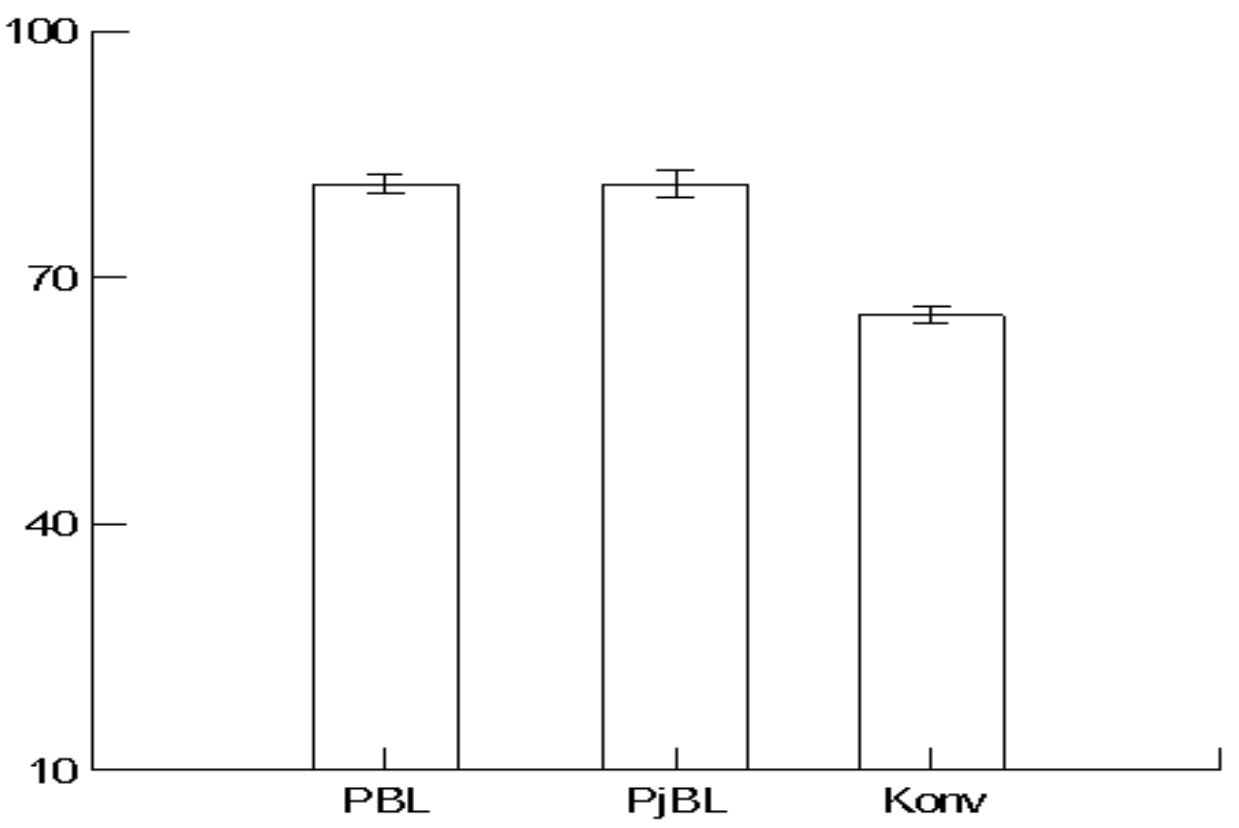

Gambar 1. Pengaruh Model Pembelajaran terhadap Hasil Belajar Siswa Kelas X SMA Negeri 2 Kota Tebingtinggi

Berdasarkan indikator soal, maka hasil belajar siswa yang dibelajarkan dengan menggunakan model problem based learning (PBL), model project based learning (PjBL) dan model pembelajaran konvensional menunjukkan bahwa rata-rata siswa yang menjawab indikator soal pertama $\overline{\boldsymbol{X}}_{ \pm}$SD 3.59 \pm 0.50 untuk model problem based learning $(\mathrm{PBL}) ; \bar{X}_{ \pm} \mathrm{SD} 3.50 \pm 0.72$ untuk model project based learning (PjBL); dan $\overline{\boldsymbol{X}}_{ \pm} \mathrm{SD} 2.95 \pm 0.75$ untuk model pembelajaran konvensional; soal kedua $\overline{\boldsymbol{X}}_{ \pm} \mathrm{SD} 3.54 \pm 0.50$ untuk model problem based learning (PBL); $\overline{\boldsymbol{X}}_{ \pm} \mathrm{SD} 3.53 \pm$ 0.55 untuk model project based learning $(\mathrm{PjBL})$; dan $\overline{\boldsymbol{X}}_{ \pm}$SD $2.80 \pm 0.41$ untuk model pembelajaran konvensional; soal ketiga $\overline{\boldsymbol{x}}_{ \pm} \mathrm{SD}$ $3.49 \pm 0.51$ untuk model problem based learning $(\mathrm{PBL}) ; \overline{\boldsymbol{X}}_{ \pm} \mathrm{SD} 2.95 \pm 0.55$ untuk 
model project based learning $(\mathrm{PjBL})$; dan $\overline{\boldsymbol{X}}_{ \pm}$ SD $2.91 \pm 0.64$ untuk model pembelajaran konvensional; soal keempat $\overline{\boldsymbol{X}}_{ \pm}$SD $3.32 \pm 0.47$ untuk model problem based learning (PBL); $\overline{\boldsymbol{X}}$ \pm SD $3.38 \pm 0.49$ untuk model project based learning (PjBL); dan $\bar{X}_{ \pm}$SD $3.25 \pm 0.49$ untuk model pembelajaran konvensional; soal kelima $\overline{\boldsymbol{X}}_{ \pm} \mathrm{SD} 2.78 \pm 0.82$ untuk model problem based learning $(\mathrm{PBL}) ; \overline{\boldsymbol{X}}_{ \pm} \mathrm{SD} 2.60 \pm 0.71$ untuk model project based learning (PjBL); dan $\overline{\boldsymbol{X}}_{ \pm}$ SD $1.57 \pm 0.73$ untuk model pembelajaran konvensional; dan soal keenam $\overline{\boldsymbol{X}}_{ \pm}$SD $2.78 \pm$ 0.72 untuk model problem based learning (PBL); $\overline{\boldsymbol{X}}_{ \pm} \mathrm{SD} 3.55 \pm 0.50$ untuk model project based learning $(\mathrm{PjBL})$; dan $\overline{\boldsymbol{X}}_{ \pm} \mathrm{SD} 2.18 \pm 0.76$ untuk model pembelajaran konvensional (Tabel $1)$.

Tabel 1. Rata-rata nilai hasil belajar siswa kelas X SMA negeri 2 kota Tebingtinggi berdasarkan indikator pada masing-masing model pembelajaran

\begin{tabular}{llccc}
\hline No & \multicolumn{1}{c}{ Indikator } & PBL & PjBL & Konvensional \\
\hline 1 & Mendeskripsikan arti keseimbangan lingkungan & $3.59 \pm 0.50$ & $3.50 \pm 0.72$ & $2.95 \pm 0.75$ \\
2 & $\begin{array}{l}\text { Mendeskripsikan pengaruh bahan pencemar terhadap } \\
\text { organism tertentu }\end{array}$ & $3.54 \pm 0.50$ & $3.53 \pm 0.55$ & $2.80 \pm 0.41$ \\
3 & $\begin{array}{l}\text { Mendeskripsikan upaya pencegahan pencemaran } \\
\text { lingkungan }\end{array}$ & $3.49 \pm 0.51$ & $2.95 \pm 0.55$ & $2.91 \pm 0.64$ \\
4 & $\begin{array}{l}\text { Menjelaskan dampak berbagai bahan pencemar terhadap } \\
\text { lingkungan }\end{array}$ & $3.32 \pm 0.47$ & $3.38 \pm 0.49$ & $3.25 \pm 0.49$ \\
5 & $\begin{array}{l}\text { Menyimpulkan pengaruh bahan pencemar terhadap } \\
\text { kehidupan organism }\end{array}$ & $2.78 \pm 0.82$ & $2.60 \pm 0.71$ & $1.57 \pm 0.73$ \\
6 & Menghasilkan produk daur ulang limbah & $2.78 \pm 0.72$ & $3.55 \pm 0.50$ & $2.18 \pm 0.76$ \\
\hline
\end{tabular}

Berdasarkan domain kognitif, maka hasil belajar siawa yang dibelajarkan dengan menggunakan model problem based learning (PBL), model project based learning (PjBL) dan model pembelajaran konvensional menunjukkan bahwa rata-rata siswa yang menjawab soal pada masing-masing domain $\mathrm{C} 1$ $\overline{\boldsymbol{X}}_{ \pm \mathrm{SD}} 3.59 \pm 0.50 ; \mathrm{C} 2 \overline{\boldsymbol{X}}_{ \pm} \mathrm{SD} 3.54 \pm 0.50 ; \mathrm{C} 3$ $\overline{\boldsymbol{X}}_{ \pm} \mathrm{SD} 3.49 \pm 0.51 ; \mathrm{C} 4 \overline{\boldsymbol{X}}_{ \pm} \mathrm{SD} 3.32 \pm 0.47 ; \mathrm{C} 5$ $\overline{\boldsymbol{X}}_{ \pm \mathrm{SD}} 2.78 \pm 0.82 ;$ dan C6 $\overline{\boldsymbol{X}}_{ \pm}$SD $2.78 \pm 0.72$ untuk model problem based learning (PBL); $\mathrm{C} 1$
$\overline{\boldsymbol{X}}_{ \pm \mathrm{SD}} 3.50 \pm 0.72 ; \mathrm{C} 2 \overline{\boldsymbol{X}}_{ \pm} \mathrm{SD} 3.53 \pm 0.55 ; \mathrm{C} 3$ $\overline{\boldsymbol{X}}_{ \pm \mathrm{SD}} 2.95 \pm 0.55 ; \mathrm{C} 4 \overline{\boldsymbol{X}}_{ \pm} \mathrm{SD} 3.38 \pm 0.49 ; \mathrm{C} 5$ $\overline{\boldsymbol{X}}_{ \pm} \mathrm{SD} 2.60 \pm 0.71 ;$ dan C6 $\overline{\boldsymbol{X}}_{ \pm}$SD $3.55 \pm 0.50$ untuk model project based learning (PjBL); dan C1 $\overline{\boldsymbol{X}}_{ \pm}$SD $2.95 \pm 0.75 ; \mathrm{C} 2 \overline{\boldsymbol{X}}_{ \pm}$SD $2.80 \pm$ $0.41 ; \mathrm{C} 3 \overline{\boldsymbol{X}}_{ \pm}$SD $2.91 \pm 0.64 ; \mathrm{C} 4 \overline{\boldsymbol{X}}_{ \pm}$SD $3.25 \pm$ $0.49 ;$ C5 $\overline{\boldsymbol{X}}_{ \pm}$SD $1.57 \pm 0.73$; dan C6 $\overline{\boldsymbol{X}}_{ \pm}$SD $2.18 \pm 0.76$ untuk model pembelajaran konvensional (Gambar 2), (Gambar 3), dan (Gambar 4).

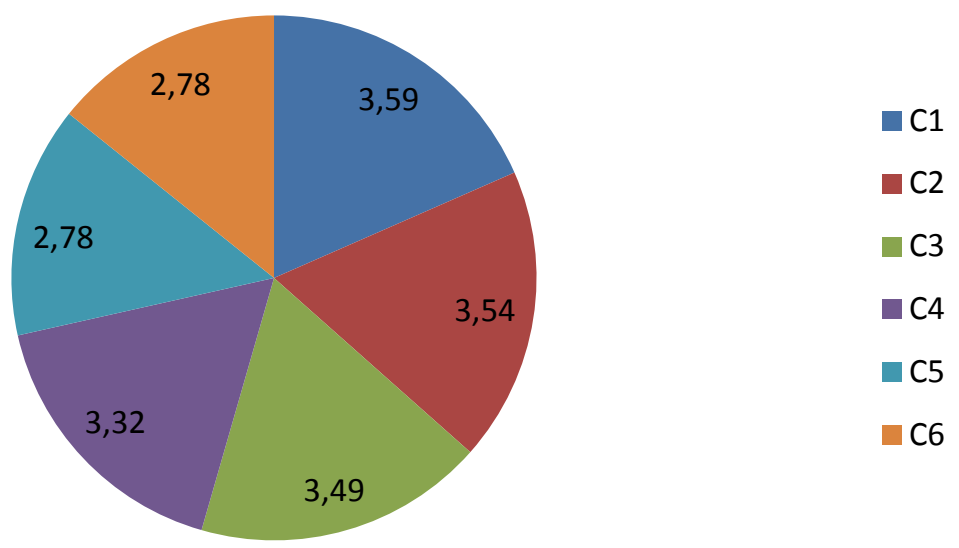

Gambar 2. Rata-Rata Nilai Hasil Belajar Siswa Kelas X SMA Negeri 2 Kota Tebingtinggi Berdasarkan Domain Kognitif pada Model PBL 


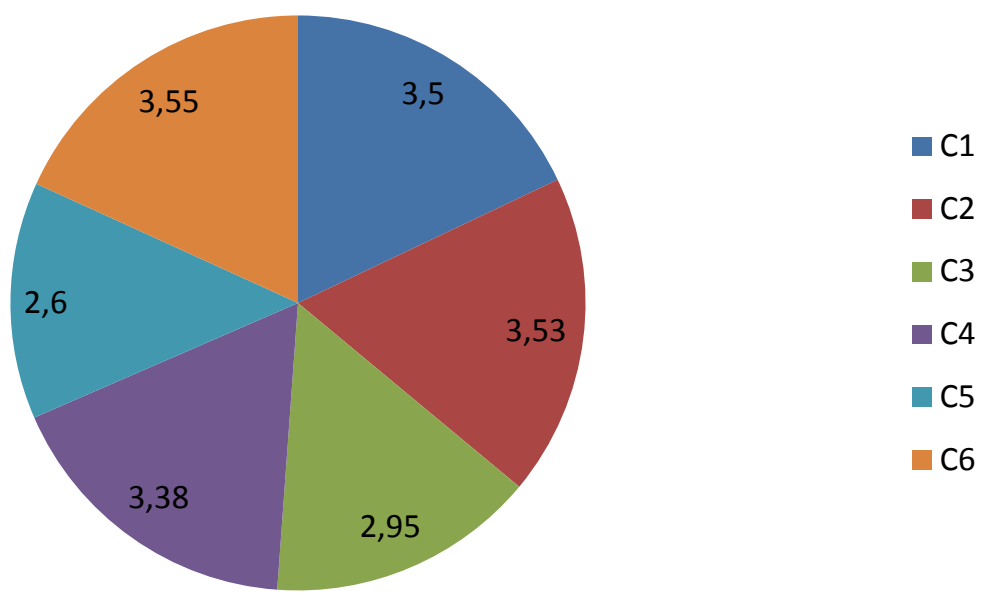

Gambar 3. Rata-Rata Nilai Hasil Belajar Siswa Kelas X SMA Negeri 2 Kota Tebingtinggi Berdasarkan Domain Kognitif pada Model PjBL

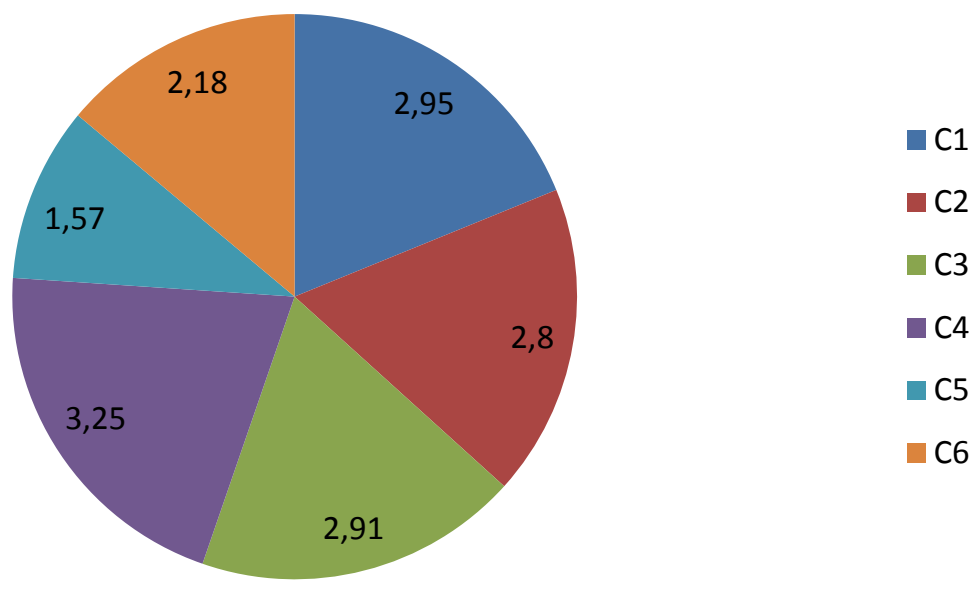

Gambar 4. Rata-Rata Nilai Hasil Belajar Siswa Kelas X SMA Negeri 2 Kota Tebingtinggi Berdasarkan Domain Kognitif pada Model Konvensional

\section{PEMBAHASAN}

Hasil belajar biologi siswa dengan menggunakan model problem based learning (PBL) $(81,46 \pm 6,59)$ lebih tinggi dibandingkan dengan model project based learning ( $\mathrm{PjBL})$ $(81,43 \pm 10,14)$ maupun dengan menggunakan model pembelajaran konvensional $(65,43 \pm$ $7,10)$.

Hasil belajar siswa berdasarkan indikator pada model problem based learning (PBL) yang ditemukan lebih besar nilai rata-ratanya daripada model project based learning (PjBL) dan model pembelajaran konvensional yaitu pada indikator soal nomor $1,2,3$, dan 5 . Sedangkan model project based learning
(PjBL) ditemukan bahwa hasil belajar siswa memiliki nilai rata-rata yang lebih besar daripada model problem based learning (PBL) dan model pembelajaran konvensional yaitu pada indikator soal nomor 4 dan 6 . Hal ini menunjukkan bahwa terdapat perbedaan yang signifikan terhadap hasil belajar siswa yang dibelajarkan dengan menggunakan problem based learning (PBL); model project based learning ( $\mathrm{PjBL})$; dan model pembelajaran konvensional.

Nilai rata-rata hasil belajar biologi siswa yang lebih tinggi pada model problem based learning (PBL) dibandingkan model project based learning $(\mathrm{PjBL})$ dan model pembelajaran konvensional dikarenakan proses pembelajaran 
yang menuntut keterlibatan siswa secara langsung pada penyelesaian masalah yang diberikan dan menemukan solusinya. Siswa diberikan lembar kerja siswa (LKS) yang berisi permasalahan terkait dunia nyata, kemudian siswa mencari informasi dengan penyelidikan terkait permasalahan dan siswa secara berkelompok melakukan diskusi untuk mengembangkan dan menyajikan hasil penemuannya. Hal ini akan membuat siswa dapat lebih memahami materi pelajaran yang dialaminya karena pengetahuan dan pemahaman diperolehnya dari hasil pengalamannya secara langsung.

Model problem based learning (PBL) merupakan model yang pembelajarannya difokuskan kepada masalah-masalah terkait dunia nyata yang diberikan guru kepada siswa untuk diselesaikan dengan seluruh pengetahuan dan keterampilan siswa dari berbagai sumber yang dapat diperolehnya (Yudawan dkk: 2015). Model problem based learning (PBL) juga dapat merangsang kemampuan siswa untuk menemukan pengetahuan atau ide baru. Secara garis besar model problem based learning (PBL) dapat menumbuhkan keaktifan dan kemandirian siswa dalam proses pembelajaran terutama dalam pemecahan suatu masalah yang terkait dengan kegiatan pembelajaran yang sedang berlangsung karena dalam model problem based learning (PBL) siswa dihadapkan pada masalah dunia nyata dan dituntut untuk dapat mencari pemecahan masalah tersebut. Hal ini akan menimbulkan rasa penasaran siswa terhadap masalah yang sedang dihadapi sehingga muncul keaktifan siswa untuk mencoba mencari pemecahannya.

Octaviani (2015), menyatakan bahwa hasil belajar siswa yang dibelajarkan dengan model problem based learning (PBL) dapat menunjukkan hasil belajar biologi yang lebih tinggi dibandingkan dengan model project based learning ( $\mathrm{PjBL}$ ) maupun dengan menggunakan model pembelajaran konvensional. Murka (2016), menyatakan bahwa terdapat perbedaan signifikan hasil belajar siswa yang diajarkan dengan menggunakan model problem based learning (PBL) dan model project based learning (PjBL).

Hasil penelitian Angkat (2013), menyimpulkan bahwa siswa yang dibelajarkan dengan model problem based learning (PBL) memiliki hasil belajar yang lebih tinggi dibandingkan dengan siswa yang dibelajarkan dengan strategi group investigation (GI) dan model pembelajaran konvensional. Sejalan dengan hal ini Saragih (2015), menyatakan bahwa terdapat pengaruh yang signifikan dari model pembelajaran (berbasis masalah, inkuiri dan konvensional) terhadap hasil belajar. Model problem based learning (PBL) dan model pembelajran inkuiri memberikan pengaruh yang lebih baik dalam meningkatkan hasil belajar mahasiswa dibandingkan dengan model pembelajaran konvensional.

Berdasarkan domain kognitif diperoleh hasil belajar siswa dengan menggunakan model problem based learning (PBL) lebih tinggi pada domain $\mathrm{C} 1$; hasil belajar siswa dengan menggunakan model project based learning (PjBL) lebih tinggi pada domain C6; dan hasil belajar siswa dengan menggunakan model pembelajaran konvensional lebih tinggi pada domain $\mathrm{C} 1$. Hal ini dikarenakan pembelajaran dengan model project based learning (PjBL) merupakan suatu pendekatan pembelajaran yang menerapkan proses belajar mengajar berorientasi pada hasil produk yang dibuat oleh siswa sebagai cara penyelesaian masalah. Model project based learning (PjBL) melibatakan siswa ke dalam berbagai tahapan yang mampu meningkatkan kognitif siswa. Melalui proyek siswa mampu melibatkan seluruh mental dan fisik, saraf, indera termasuk kecakapan sosial dengan melakuan banyak hal sekaligus (Purworini, 2006).

Sani (2014), model project based learning (PjBL) didefinisikan sebagai suatu model pembelajaran yang bertujuan untuk mengatasi permasalahan dunia nyata dengan melibatkatkan aktivitas siswa mulai dengan merancang, membuat, dan menghasilkan sebuah produk yang dilakukan dalam jangka waktu panjang.

Maiderawati (2015), mengungkapkan bahwa terdapat pengaruh model pembelajaran project based learning ( $\mathrm{PjBL}$ ), kooperatif tipe NHT dan konvensional terhadap hasil belajar biologi siswa SMA N 1 Telukkuantan Riau. Huda (2009), mengungkapkan bahwa bahwa PjBL memberikan kemampuan kognitif yang menghasilkan peningkatan pembelajaran dan kemampuan untuk lebih baik mempertahankan/menerapkan pengetahuan. Selanjutnya Titin dkk (2012), menemukan bahwa terjadi peningkatan hasil belajar mahasiswa pada aspek kognitif, apektif, kemampuan proses sains dan sikap peduli lingkungan terhadap siswa yang menggunakan model STM berbasis proyek. 


\section{SIMPULAN}

Berdasarkan hasil dan pembahasan penelitian disimpulkan bahwa terdapat pengaruh model problem based learning (PBL), project based learning (PjBL) dan model pembelajaran konvensional terhadap hasil belajar biologi siswa dengan nilai $(\mathrm{P}=0,025)$. Hasil belajar biologi siswa yang dibelajarkan dengan model pembelajaran problem based learning (PBL) dengan nilai rata-rata 81,46 \pm 6,59 lebih tinggi dari hasil belajar biologi siswa yang dibelajarkan dengan model pembelajaran project based learning (PjBL) dengan nilai rata-rata 81,43 $\pm 10,14$ dan hasil belajar biologi siswa yang dibelajarkan dengan model pembelajaran konvensional dengan nilai ratarata $65,43 \pm 7,10$. Berdasarkan rata-rata nilai hasil belajar biologi menunjukkan bahwa model problem based learning (PBL) memberikan pengaruh sebesar $0,3 \%$ lebih tinggi dibandingkan dengan model project based learning ( $\mathrm{PjBL})$ dan lebih tinggi secara signifikan sebesar $24,49 \%$ dibandingkan dengan model pembelajaran konvensional. Model project based learning (PjBL) memberikan pengaruh signifikan sebesar 24,45 $\%$ dibandingkan dengan model pembelajaran konvensional. Hasil belajar siswa berdasarkan indikator pada model problem based learning (PBL) yang ditemukan lebih besar nilai rataratanya daripada model project based learning (PjBL) dan model pembelajaran konvensional yaitu pada indikator soal nomor 1, 2, 3, dan 5 . Sedangkan model project based learning (PjBL) ditemukan bahwa hasil belajar siswa memiliki nilai rata-rata yang lebih besar daripada model problem based learning (PBL) dan model pembelajaran konvensional yaitu pada indikator soal nomor 4 dan 6. Berdasarkan domain kognitif diperoleh hasil belajar siswa dengan menggunakan model problem based learning (PBL) lebih tinggi pada domain $\mathrm{C} 1$; hasil belajar siswa dengan menggunakan model project based learning ( $\mathrm{PjBL}$ ) lebih tinggi pada domain C6; dan hasil belajar siswa dengan menggunakan model pembelajaran konvensional lebih tinggi pada domain $\mathrm{C}$.

\section{DAFTAR PUSTAKA}

Angkat, A. 2013. Pengaruh Strategi Pembelajaran Terhadap Keterampilan Proses Sains, Sikap Ilmiah, dan Hasil Belajar Siswa Tentang Ekologi di SMK Negeri 1 Penanggalan Kota Subussalam. Tesis. Program Pascasarjana. Medan: Universitas Negeri Medan
Bangun, J. 2012. Pengaruh Strategi Pembelajaran terhadap Aktivitas Siswa, Hasil Belajar Biologi dan Kemampuan Berpikir Kritis Siswa SMP Negeri 21 Medan,. Tesis. Program zascasarjana. Medan: Universitas Negeri Medan

Huda, A. 2009. Peningkatan Mutu Pembelajaran dengan Pembelajaran Berbasis Proyek. (online) diakses: 2 Desember 2014

Mahanal, S. Darmawan, E. Corebima, A. D. Zubaidah, S. 2009. Pengaruh Pembelajaran Project Based Learning (PjBL) pada Materi Ekosistem terhadap Sikap dan Hasil Belajar Siswa SMAN 2 Malang. Jurusan Biologi FMIPA. Malang: Universitas Negeri Malang

Maiderawati. 2015. Pengaruh Model Pembelajaran terhadap Sikap Ilmiah, Kemampuan Berpikir Kreatif dan Hasil Belajar Biologi Siswa SMAN 1 Telukkuantan Riau. Tesis. Program Pascasarjana. Medan: Universitas Negeri Medan

Murka, R. 2016. Perbedaan Hasil Belajar Siswa Menggunakan Model Project Based Learning pada Materi Pencemaran dan Pelestarian Lingkungan Hidup di Kelas X SMA Prayatna Medan T.P. 2015/2016. Tesis. Program Pascasarjana. Medan: Universitas Negeri Medan

Octaviani, S, A. 2015. Perbedaan Hasil Belajar Biologi Antara Pembelajaran Berbasis Masalah Dengan Pembelajaran Berbasis Proyek Pada Siswa Kelas VII SMP Muhammadiyah 2 Surakarta Tahun Ajaran 2014/2015. Tesis. Program Studi Pendidikan Biologi Fakultas Keguruan dan Ilmu Pendidikan Universitas Muhammadiyah Surakarta

Purworini, S. E. 2006. Pembelajaran Berbasis Proyek Sebagai Upaya Mengembangkan Habit Of Mind. Studi Kasus di SMP Nasional KPS Balikpapan. Jurnal Pendidikan Inovatif. 1 (2): 17-19

Rahmawati, F. 2014. Penerapan Strategi Project Based Learning (PjBL) Berbantuan Modul Pengelolaan Sampah Berbasis 6M Untuk Meningkatkan Pengetahuan, Sikap, dan Perilaku Siswa SMPN 26 Malang Guna Menuju Program Sekolah Adiwiyata. Tesis. Program Studi Pendidikan Biologi. Malang: Pascasarjana Universitas Negeri Malang

Saragih, S. Z. 2015. Pengaruh Model Pembelajaran terhadap Kemampuan Berpikir Kritis, Kecakapan Sosial dan Hasil Belajar Pengetahuan Lingkungan. Tesis. Program Pascasarjana. Medan: Universitas Negeri Medan

Sembiring, F. R. 2014. Pengaruh Strategi Peta Konsep dalam Problem Based Learning Terhadap Hasil Belajar dan Kemampuan Berpikir Kritis pada kelas X Madrasa Aliyah Negeri Binjai. Tesis. Program Pasca Sarjana. Medan: Universitas Negeri Medan

Suryobroto, S. 2002. Proses Belajar Mengajar. Jakarta: Rineka Cipta

Titin, Sunarno, Masykuri, 2012. Pembelajaran Biologi Menggunakan Model Sains Teknologi Masyarakat (STM) Berbasis Proyek untuk 
Meningkatkan Hasil Belajar dan Sikap Peduli Lingkungan. Jurnal Inkuiri. 1(3): 245-257

Wahyudi. 2002. Tingkat Pemahaman Siswa terhadap Materi Pembelajaran IPA. Jurnal Pendidikan dan Kebudayaan. 3(6): 389-401
Yudawan, A. Rubini, B. Kurniasih, S. 2015. Model Pembelajaran Problem Based Learning dan Guided Discovery Learning Berbantu Media Pembelajaran Muvis Terhadap Literasi. Sciences Pedagogia. Volume 7 (2) 